\title{
Understanding the Relationship Between Density and Neighbourhood Environmental Quality - A Framework for Assessing Indian Cities
}

\author{
Swati Dutta ${ }^{*}$, Suchandra Bardhan ${ }^{2}$, Sanjukkta Bhaduri ${ }^{3}$, Siddhartha Koduru ${ }^{4}$ \\ ${ }^{1}$ University Institute of Architecture, Chandigarh University, NH-95, Ludhiana - Chandigarh State Highway, Punjab 140413, \\ India \\ ${ }^{2}$ Department of Architecture, Jadavpur University, 188, Raja S.C. Mallick Road, Kolkata 700032, India \\ ${ }^{3}$ Department of Urban Planning, School of Planning and Architecture, 4-Block-B, Indraprastha Estate, New Delhi 110002, \\ India \\ ${ }^{4}$ University Institute of Design, Chandigarh University, NH-95, Ludhiana - Chandigarh State Highway, Punjab 140413, India
}

Corresponding Author Email: swati.e10056@cumail.in

https://doi.org/10.18280/ijsdp.150711

Received: 10 June 2020

Accepted: 23 September 2020

Keywords:
Indian cities, intra-city residential
patterns, neighborhood environmental
quality (NEQ), physical density, rapid
urbanization, urban environmental
quality (UEQ)

Keywords:

Indian cities, intra-city residential quality $(U E Q)$

\begin{abstract}
The paper brings forth key issues concerning environmentally sustainable development of cities in the wake of rapid urbanization and shows the pathway for future sustainable cities of India. Studies reveal that around the world smaller cities are going to accommodate a larger number of people in the future and be the engines of economic growth and development. A thorough study to ascertain intra-city residential patterns is undertaken. It is perceived that to establish a relationship between residential patterns based on built-forms, distribution of dwelling units, population distribution, etc. (collectively known as physical density) and environmental quality, it is quintessential that local environmental problems are studied at the neighbourhood level. Following this, the terms density and environmental quality are defined and common measures adopted to describe the different types of physical density and indicators to assess neighbourhood environmental quality (NEQ) are identified. The literature review reveals that studies taking into account physical aspects of the built environment and their impact on urban environmental quality (UEQ) are sparse especially in the Indian context, thus justifying the scope of the work. The study concludes with the discussion of impacts of increasing density on environmental quality and identification of a set of variables as emerging from the literature review to help formulate an adaptive indicator framework for assessing NEQ in Indian cities.
\end{abstract}

\section{INTRODUCTION}

Existing literature indicates that majority of the cities around the world are witnessing explosive increase in urban population resulting in strain on existing systems that is further manifesting into chaotic environmental quality [1]. Environmental problems due to unplanned development resulting in poor environmental quality are immediate, localized and health threatening for the residents of small or low income cities. On the contrary, in case of middle income cities the problems are citywide or regional and high income cities have fewer problems and good environmental quality. Higher income cities though better in environmental quality pose a threat at global scale due to high consumption rate of resources thereby effecting ecological and environmental sustainability. There is a visible transition in environmental problems dealt by cities as they ascend the level of transformation [2].

Smaller cities in India face similar issues but differ in the environmental problems faced by larger cities due to their development and growth patterns. Environmental problems in low income (small and medium) towns due to absence of basic services and lack of infrastructure are localized. On the other hand, the middle, upper middle and high income cities (larger cities and metropolises) are prone to undesirable growth patterns accompanied by transgression and transformation that affect the overall environment of the city and its inhabitants. Migration of people from small cities and rural areas to these cities in hope of job security and comfortable living expose the city and its hinterland to be exploited and plundered for personal gains [3].

Development authorities try to yield profit due to excessive demand on land supported by bureaucratic and political jargon resulting in diversion from planned physical growth of the city. Private players become major decision makers in modification and relaxation of zoning regulations and byelaws to promote their personal goals. Land use changes and physical development are carried out without an afterthought of the impact. Major parks and green spaces which act as the lungs of cities either disappear or are subjected to land use conversion for commercial or infrastructure facilities. Private sector influenced urban development aimed to make profit result in high land prices and the alienation of the low income and poor from the development and decision making process. They are forced to encroach upon the nearest available open land resulting in the development of slums and squatters in the middle of planned urban landscape. Most of these land parcels either have no ownership or are prone to poor environmental 
quality, natural disasters or hazardous conditions [4].

Along the periphery of the cities eco-sensitive areas, forests, agricultural lands present a dismal scene of conversion into areas for residential or commercial projects by licensed and unlicensed private colonizers. Unregulated growth and poor development patterns result in unmanaged or mismanaged waste, increasing noise pollution due to increase in traffic, poor water and air quality along the periphery thereby impacting the already congested city. Preserving and preventing the degradation of culture and heritage sites, controlling encroachment of historic public spaces add to the concerns of protecting our past. Deterioration of urban environment results in putting not only the environment but also people's lives in threat [5-9]. In this context, study of particular urban form typologies, growth and development patterns is significant as they have a profound impact on urban environmental quality (UEQ).

Environmental quality of urban areas is subject to complex problems and requires careful analysis of various parameters that make up the environment. There is a strong link between the quality of the built environment and the impact it has on health, social, economic and environmental outcomes [10]. Existing studies have highlighted the need to promote the role of local stakeholders in addressing urban environmental problems at local level before they manifest into global challenges as visible in case of the Coronavirus or COVID-19 pandemic that has impacted major urban areas and brought them to a standstill. To reduce environmental decay and improve local socio-economic conditions Local Agenda 21 (1997) was formulated which promotes local dedicated actions. In the present scenario, lockdown and containment have been adopted as solutions to control the spread of the virus. Local actions starting from the household as the smallest unit; neighbourhood or ward at the primary level and district at the next level have ensured effective control of the situation. We have become more vigilant about the maintenance and upkeep of our surroundings and caring about the people around us [11]. Hence, in order to plan more inclusive and just urban futures, it is pertinent to assess the neighborhood environmental quality to ensure cleaner and sustainable environment for our city residents.

The present study intends to identify variables that can help in the measurement of NEQ indicators for subsequent generation of an 'Environmental Quality Index' that can serve as an instrument to classify different neighborhoods of the city according to the level of environmental quality. This in turn shall enable local actions by the residents and urban local bodies to improve the environmental quality in old and new neighbourhoods. The future course of work also proposes to identify significant correlations between physical density variables and indicators of NEQ to give suggestions for modification of different built-form characteristics to achieve better environmental and spatial quality in the upcoming neighbourhoods.

\section{URBANIZATION IN INDIA}

Urbanization in India began to accelerate after independence, due to the country's adoption of a mixed economy, which gave rise to the development of the private sector. Population residing in urban areas in India, according to 1901 census, was $11.4 \%$. This count increased to $28.53 \%$ according to 2001 census, and crossed $30 \%$ as per 2011 census, standing at $31.16 \%$.
Presently with an urban population of 377 million (approximately $30 \%$ ) of 1.2 billion as per Census 2011, INDIA is going to witness rapid urbanization with an increase in urban population to $60 \%$ by 2030 and shift in economic development from agriculture to other sectors. China and India with populations of 1.3 billion and 1.2 billion, respectively account collectively for almost 40 per cent of the world's population. Over the past three decades, India's population has grown at a much faster rate than China. Projections from the United Nations (2008) suggest that while India's population will continue to grow, albeit at a somewhat slower pace than in the past, China's population will increase more slowly and eventually begin to decline around 2030 when India's population is expected to surpass that of China.

In the first decade of 21 st century, India has emerged as the world's second fastest growing economy (after China). This has happened due to:

- The change from the post-independence socialist development model with strong rural bias to a more open and varied economy

- Spread of primary education - 51\% in 1991 to projected $90 \%$ in 2020

- Unprecedented shift of middle class from small town and rural population to the cities

- Expected formation of around 13 Urban Agglomerations of more than 10 million people by 2025 [12]

The explosive growth in the last ten years of Gurugram and Bangalore is only a foretaste of what will be witnessed in the next few decades. The key issue is then how does urban India already struggling with the existing population deal with the influx of approximately 343 million more people in an environmentally conducive way?

Also, it is important to note that smaller towns form a major portion of India's urban centers. As per 2011 census, out of the 8000 urban centers identified, only 53 cities have a population of over 1 million. Out of the total urban population, only twenty percent live in million plus cities. Eighty percent of the urban population lives in cities and towns of population $\leq 1$ million [13].

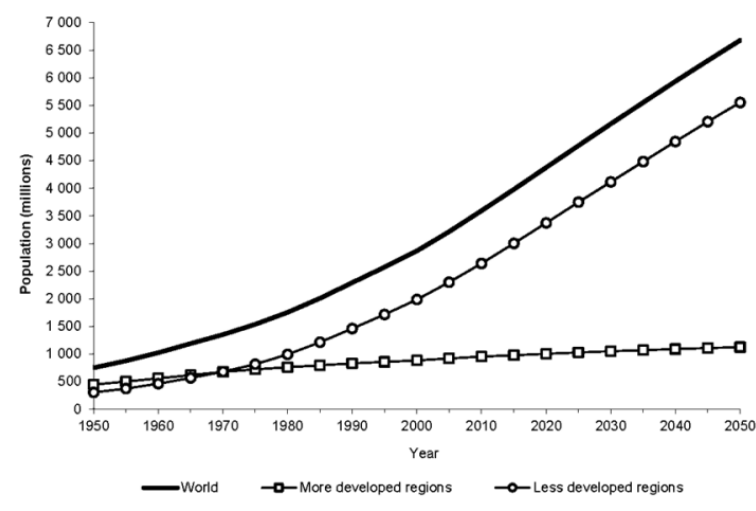

Figure 1. Estimated and Projected Urban Population of the World, the more developed regions and the less developed regions, 1950-2050

Correspondingly, the urban population growth trends shown in Figure 1 [14] indicate that less developed regions will show a much higher growth in urban population than more developed regions, hence the most meaningful approach in our case is to expect the rapid growth of Class I ( $0.1-1$ million $)$ cities and put them centrally on the development agenda. This does not however mean that mega cities and larger 
metropolises would be neglected as they will continue playing a significant role in absorbing future growth, but for the near future cities with $0.1-1$ million population will hold the key to urbanization in India.

\section{INTRA-CITY RESIDENTIAL PATTERNS IN INDIAN CITIES}

By and large it is seen that within a city the patterns of urbanization differ from one location to another depending on factors like topography, development controls and land use regulations, historic, cultural and socio-economic preference of people along with political developments. Urban development with such varying patterns results in varying population densities, concentration of commercial and residential development, and extent of open spaces along with amounts of land devoted to non-urban uses [15]. A close observation of major Indian cities can verify these facts.

The traditional Indian city comprising of walled city with inner core are compact (low rise high density) in character primarily designed for pedestrian and certain marked routes for vehicular modes like Tongas (horse driven carts) and cycle rickshaws. The compact built up mass with monolithic volumes punctured by small openings provide for light, ventilation and movement. The organic pattern based settlement development ensures that the domestic life is closely knit to a physical density comprising of streets and Chowpals (public squares) and large courtyards acting as essential public open spaces. A major portion of these areas comprise of built up volume of about $70 \%$ in comparison to pedestrian streets and courtyards that occupy only $30 \%$ of the total area. Buildings ideally ground plus two or three storey high are compactly placed to shield the streets from the sun's heat. This ensures that the streets always remain cool for pedestrians even in the hot summers, and the orientation of the streets in relation to the localized wind currents aids in further cooling. Old parts of Shahjahanabad (Delhi), Jaisalmer and Jaipur (Rajasthan), Ahmedabad (Gujarat), etc. exhibit these characteristics [16].

In other cases that are dominated by the colonial developments, low rise low density developments are visible. These annex settlements either in form of cantonment; civil lines or railways colonies are more isolated, organized and regular in pattern with buildings and spacious outdoors. The buildings are distinguishable and grouped based on their specific functions and have high level of sanitation as found in Ahmedabad, Ambala, Amritsar, Meerut, etc. to name a few. They are a contrast to the traditional indigenous cities that are irregular and organic in composition and tend to have developed around or alongside significant entity either in form of a fortress, royal palace, holy place or an emerging trade based activity or village like Murshidabad (administration), Banaras (religion), Calicut (trade), etc. [17, 18].

Accelerated industrialization fueled rapid urbanization in the newer parts of the city resulting in haphazard development in and around the old city areas and transit corridors. Increase in industrial and commercial activities lead to job opportunities to residents and promoted migration. High density (medium rise high density or high rise high density) self-referential development comprising of heterogeneous units without any reaction to their surrounding adjacencies or surrounding streets in the locality came into existence. They were accepted due to their vicinity to the workplace ensuring cheap transit cost. Haphazard mushrooming of towers comprising of slabs by capitalists in unchecked and rapacious manner led to the decay of coherent urban form based city making and denial of public realm [19].

Lastly, the residential development seen in most city outskirts are the gated communities dominated by high rise apartment blocks, community open space and shared facilities and amenities. Though these communities themselves might be high rise high density enclaves but at the scale of the city, lying on the fringes they are generally part of a car favoring low-density suburb, which does not support the vitality of urban life and its traditional energy thereby rendering them highly unsustainable [20].

Varied configurations and built forms along with their geographic extent in relation to the population distribution characterize the urban form of a city. To establish a relationship between diverse residential patterns based on variables like built forms, population distribution, distribution of dwelling units; and environmental quality, it is essential to study the local environmental problems associated with these varied patterns found in different neighborhoods in a city.

\section{UNDERSTANDING PHYSICAL DENSITY}

Density in its various perspective forms has been studied extensively including - social, physical, environmental and psychological [21-27]. According to Cheng [28], physical density is a numerical measure of the concentration of individuals or physical structures within a given geographical unit. Physical density in its measurable form is divided broadly into two categories: people density and building density. People density is expressed as the number of people or households per given area, while building density is defined as the ratio of building structures to an area unit. Common measures of people and building densities are outlined as follows:

\section{Measures of People Density:}

Regional Density - Regional density is the ratio of a population to the land area of a region. It is frequently used as an indicator in national planning policy.

Residential Density - Residential density is the ratio of a population to residential land area. This measure can be further classified in terms of net and gross residential densities. As per the Model Building Byelaws 2016 of the Town and Country Planning Organisation (TCPO), Ministry of Urban Development, Govt. of India, the residential density is expressed in terms of the number of dwelling units per hectare.

\section{Measures of Building Density:}

Plot Ratio (Floor Area Ratio) - It is the ratio of total gross floor area of a development to its site area. It is extensively adopted for the regulation of land-use zoning and development control. Also, maximum plot ratio is often controlled in order to govern the extent of build-up and prevent overdevelopment.

Plot Coverage - It represents the ratio of the building footprint area to its plot area. Plot coverage of individual developments is controlled to regulate the built-up and to preserve areas for greenery and landscaping.

Building density has an intricate relationship with urban morphology; it plays an important role in the shaping of urban form. Different combinations of plot ratio and plot coverage take the form of a variety of built forms. They describe the image of an area and help in determining the patterns of land use and buildings. 
Table 1. Physical density variables

\begin{tabular}{|c|c|c|}
\hline S.No & Type of Density & Measurement Units \\
\hline 1. & People Density & \\
\hline (i) & Population Density & Persons per hectare (pph) \\
\hline (ii) & Residential Density & Dwelling Units per hectare (DUs/ha) \\
\hline 2. & Building Density & \\
\hline (iii) & Plot Ratio or FAR or FSI & Ratio (expressed as $1,1.5,2,3$, etc.) \\
\hline (iv) & Plot Coverage & Percentage (expressed as $30 \%, 40 \%$, etc.) \\
\hline 3. & Spatial Density & \\
\hline (v) & Height to Width Ratio & Ratio (expressed as $1: 1,1: 1.5,2: 1$, etc.) \\
\hline (vi) & Distribution of Open Spaces & Percentage (expressed as $30 \%, 40 \%$, etc.) \\
\hline (vii) & Distribution of Roads and Sidewalks & Road Length per hectare (m/ha) \% of Sidewalks \\
\hline (viii) & $\begin{array}{l}\text { Distribution of Services (domestic waste, drainage, } \\
\text { sewerage, streetlights, etc.) }\end{array}$ & $\begin{array}{l}\text { Road Length attended/covered by waste collection and drainage system } \\
\text { No. of properties connected to the sewerage } \\
\text { c/c spacing of streetlights }\end{array}$ \\
\hline
\end{tabular}

\section{Measures of Spatial Density:}

Spatial density refers to the perception of density with respect to the relationship among spatial elements such as height of buildings to street width ratio, spacing and juxtaposition. High spatial density is related to environmental qualities, such as high degree of enclosure, intricacy of spaces and high activity levels. The various densities along with their measurement units are summarized in Table 1.

\subsection{People density in Indian cities}

Indian cities occupy $10 \%$ of the world's total urban area and house more than one tenth of the world's urban population [29]. A study by Pandit [30] on relationship between urban density and transit oriented development (TOD) highlights that as part of Indian Smart Cities Mission 2015, out of the 33 smart cities announced the average densities varied from 10pph (Dharamshala) to 265pph (Chennai). The average density of the cities is $59 \mathrm{pph}$, and even the 75 th percentile is $87 \mathrm{pph}$ (Bhagalpur). It could be misleading observing low average densities of Indian cities, but the densities in their core areas is very high generating a high demand for provision of public transit system. To attain uniform development, the low density areas need re-densification along with upgrading of existing urban spaces like pedestrian amenities, nonmotorized transit systems, increasing housing units, etc.

Similarly, Ray's [31] study on Sustainable Urban Form for Indian Cities advocates several aspects like mixed land use, strong public transport access, horizontal and vertical randomization of buildings with low coverage and high FAR. She proposes medium to high density neighbourhoods with urban blocks of 100-200 hectares having 4-7 storeyed buildings and 40-80pph at the neighbourhood level. Dash's [32] Report shows that the Town and Country Planning (TCP) Department, New Delhi, India has increased the density of population in case of group housing societies for instance in Gurugram to 300ppa (750pph) as against the earlier standard of 250ppa (625pph). Though this is much less than other cities for e.g. in case of Faridabad, for group housing the density of population is 400ppa (1000pph), the increase in density is a welcome sign as there is high residential demand and the developers building high-rises can add more flats that will not only help create more housing facilities, but also put a check on the sky-rocketing property prices. Similarly other states (e.g. Haryana) have revised the densities for plotted development from 100ppa (250pph) to 120ppa (300pph).

Probing further, studies indicate that the revised URDPFI Guidelines [33] suggest 125-175pph as the developed area average densities for metropolitan cities of the country.
However primary and secondary studies indicate much higher gross densities in the metro cities. Densities observed vary from as low as 95pph to as high as 798pph with an average density of 447pph across different case study cities [34].

\subsection{Building density in Indian cities}

There is a strong pitch to increase building density measured by permissible Plot Ratio or FAR in Indian cities considering the space crunch in the city. Higher FAR brings in more supply into the market, creating more homes. But vertical growth must be planned. Without the required infrastructural up gradations, a higher FAR result in extra load on the facilities and services and degrades the environmental quality. It must be noted that India lags behind in FAR norms compared to top cities of the world. Global cities such as Tokyo, Shanghai, New York and Hong Kong offer FAR limits between 10 and 15. Comparatively in Mumbai, the permissible FAR ranges between 2.5 and 4 for redevelopment projects and between 1.33 and 4 for non-redevelopment projects [35].

Another important aspect to be understood is as Patel [36] brings forth through his study is that higher FAR does not necessarily imply higher density. It actually depends on the amount of floor space occupied by each resident. In addition, it is also important to understand that public ground area consisting of streets (carriageways and footpaths) and parks etc. available to each resident of the area is also instrumental in establishing how good or bad the locality is. Increasing FAR and plot coverage will bring in more people within the same area thus leading to increased impoverishment for all the older residents in respect of what each family enjoys by way of the infrastructure of schools, medical facilities, parks and playgrounds, as well as roads, water supply and sanitation [37].

Studying and comparing FAR and building regulations for residential buildings across different cities in India shows that most of the cities have their own set of rules and regulations as considered appropriate with respect to the population distribution, mix of housing, type of infrastructure and future development strategies (Figure 2) [35]. It is seen that within the Class I cities, Tier I cities (population $\geq 4$ million) have FAR ranging from 1.2 to 3.25 with exception of Delhi and Mumbai where FAR -4 is permitted in redevelopment projects and low FAR ranging from 0.5 to 1 is assigned to the suburbs of Mumbai. Tier II cities $(0.75$ million < population < 4 million) have FAR ranging from 1 to 2 generally. Plot coverage in both cases vary from $35 \%-70 \%$ generally with few exceptions of higher plot coverage. Additional FAR can be purchased in certain cities. The intent is not to increase the 
number of families but to increase the average size of the units. However, considerable cost is incurred to build the additional floor space as a result of the purchased FAR which is met by accommodating more people within the area. Thus, when FAR is increased, the load on the city's infrastructure increases with increase in population. Authorities charge extra for supporting the high population density and retrofitting of existing infrastructure. In an ideal condition, additional purchasable FAR is expected to raise additional capital for providing extra infrastructure. However, in real the situation is seldom so consequently leading to several problems and degraded urban environment [38].

\subsection{Spatial density in Indian cities}

It is known from empirical studies that perceptions of density sometimes affect the acceptable levels of physical density [26, 39]. Hence, certain important parameters of spatial density like building height to street width ratio, proximity to daily needs, distribution of open spaces, and distribution of roads, streetlights and level of services are studied.

Raman's [40] empirical analyses of six neighbourhoods of south-east England indicate that characteristics of social networks change enormously depending on density and layout. Low-density neighbourhoods (around 25-30 dwellings per hectare) in street form are characterized by high level informal contacts and interactions while high-density neighbourhoods (160-270 dwellings per hectare) with complex spatial layouts have smaller but stronger social networks. The level of social interaction in outdoor public spaces at ground floor level is highest in medium density neighbourhoods (51-100 dwellings per hectare) as they are physically and visually more integrated with the other neighbourhood spaces. Thus, the social environment is directly linked to the built form or the spatial and physical characteristics of the urban neighbourhoods.

Similarly, Dave [39] shows through the study of 11 case study neighbourhoods of Mumbai that both physical and perceived densities have significant impact on the social, economic and environmental sustainability of the neighbourhood. While dense neighbourhoods are associated with less living space, less amount of open spaces and parks, less road infrastructure per household, higher feelings of insecurity and vandalism especially during the night time, higher traffic congestion, problems of pollution and poor air quality; they have higher sewage pipes per hectare and more walking to work and shopping trips and greater use of public transport because of the proximity of transport nodes.

There are standard regulations of building height and abutting road width as per the building regulations of different cities. However, there are no regulations for street orientation for favourable wind movements and ensuing shade and ventilation. Architectural research and implementation in various projects by Charles Correa and Doshi help to understand the micro-climatic benefits achieved as a result of such consideration $[41,42]$.

The URDPFI Guidelines 2014 recommend 1.2-1.4 hectares per 1000 population or $12-14$ sqm per capita for community open spaces while it is seen that the open spaces have been constantly decreasing because of rapid urbanization and increase in built-up areas in Indian cities. Mumbai has just $1.28 \mathrm{sqm}$ of open space per person. In comparison London has 31.68 sqm per person, New York has 26.4 sqm per person and Chicago has $17.6 \mathrm{sqm}$ of open space per person. Similarly, Jaipur has about 2 sqm of open space per person which is much less than the prescribed standards [43-45].

Considering distribution of roads, India is positioned $96^{\text {th }}$ in the world, with a road length to per thousand-person ratio of 4.87 as against Australia which leads at $36.08 \mathrm{~km}$ per thousand people followed by Canada at $31.05 \mathrm{~km}$ and United States at $20.55 \mathrm{~km}$ per thousand people. The percentage of paved road length is also much lower when compared with countries like France, UK, China, etc. [46]. Lesser road length per capita implies higher traffic congestion, problems of pollution and poor air quality thus affecting the urban environment significantly.

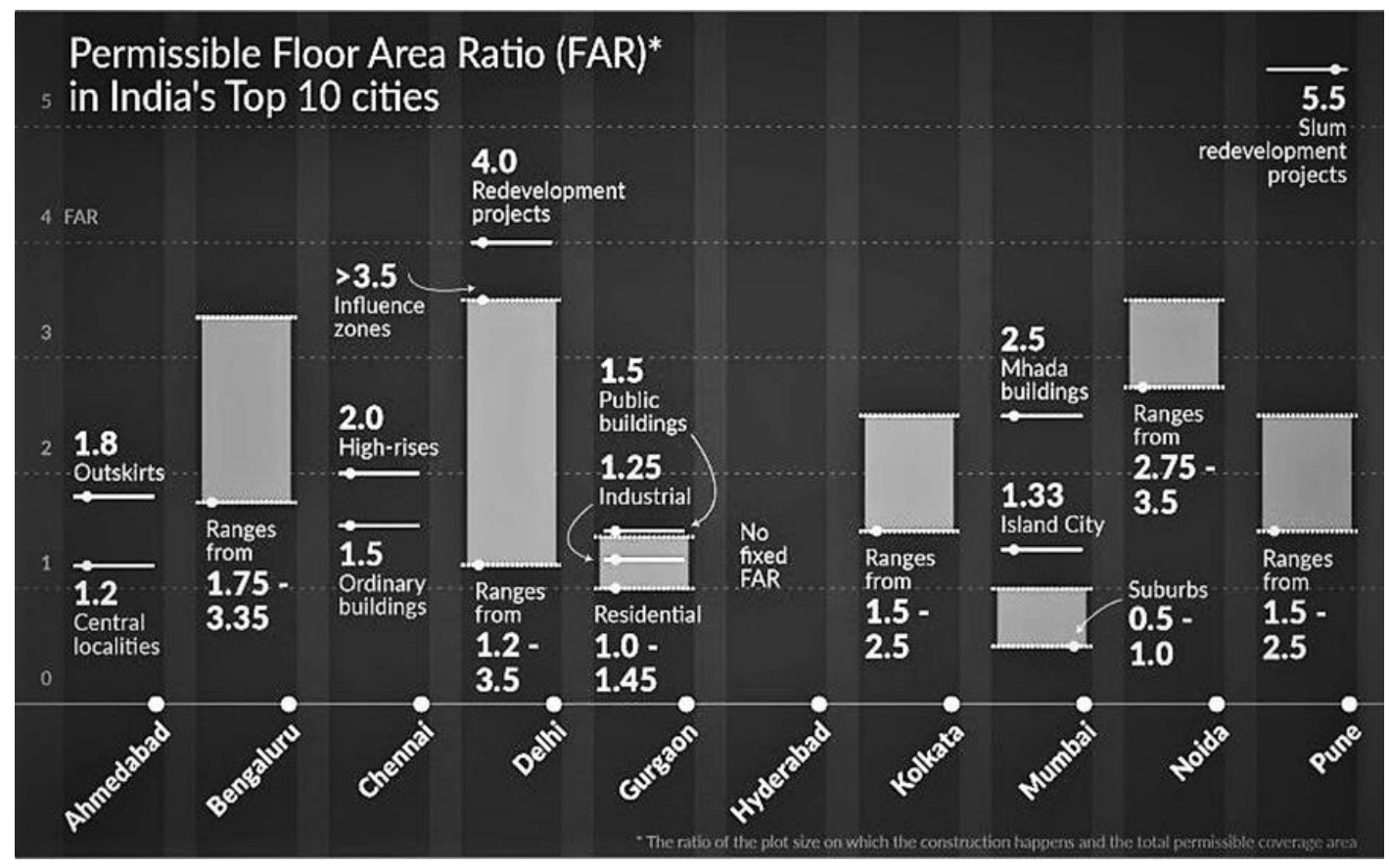

Figure 2. Permissible FAR in 10 Indian cities 
Another important aspect related to roads, are the provision of streetlights. The Handbook of Service Level Benchmarking, Ministry of Urban Development, Govt. of India lays down norms for number and spacing of streetlights to be adopted in the urban areas. There is a need for devising a well thought out way to prevent wastage of electricity. The government can think of implementing Automatic Street Light Control System using LDR (Light Dependent Resistor), which automatically switches off lights when sunlight fall on it. Poor maintenance of street lights is another problem faced by most citizens. The municipalities are hard pressed for funds and it is the citizens who have to face the consequences [47].

As per the Report on Indian Urban Infrastructure and Services (2011); several indicators are developed to ascertain the level of services in Indian cities. For solid waste management, the cleanliness indicator measures length of roads attended by cleanliness service divided by the total length of the roads of the area; the drainage indicator is given by total length of primary, secondary and tertiary drains (made of permanent material and covered) divided by total length of road network for managing storm water runoff while the sewage indicator measures total number of properties with direct connection to sewage network divided by the total number of properties in the service area. The handbook lays down $100 \%$ as the minimum standards for the above mentioned indicators. However, the situation is quite poor in most of our rapidly urbanizing cities.

In case of solid waste, the actual problem is of storing, transporting and disposing the waste that leads to insanitary conditions in our urban areas. As far as storm water drains are concerned, the Ministry surveyed 13 states in 2010-11. A total of 1,383 urban local bodies (ULBs) responded, of which 104 were municipal corporations in large cities. As many as 56 of these 104 cities had coverage below 50\% (a level termed by the Ministry as needing "immediate action for improvement") and 93 had coverage below $75 \%$ [48].

As per census 2011, at country level, there is no sewage facility in $48.9 \%$ households, while $33 \%$ households have only open sewage system. Nearly $80 \%$ of the sewage generated in India flows untreated into its rivers, lakes and ponds, turning the water sources too polluted to use. Indian cities produce nearly 40,000 million litres of sewage per day, enough to irrigate 9 million hectares and barely $20 \%$ of this is treated. Almost half of the urban Indian population still depends upon groundwater sources for drinking, cooking and bathing which puts them at direct risk from the polluted water [49].

Thus, the poor conditions of most of the spatial density parameters suggests that evaluation of urban neighbourhoods should become an increasingly important issue for planners, urban designers, residents and decision makers. There is need for a theoretical framework, supported by empirical observations and classification based on systematic description of the urban structure at micro level to process the information accumulated and guide the process of micro and macro level planning for a renewable urban structure [25].

\section{NEIGHBOURHOOD ENVIRONMENTAL QUALITY (NEQ)}

The term "neighbourhood" represents an intermediate urban scale. It usually includes dwellings, infrastructure and community services. It is a scale in which multiple disciplines are involved, including environmental, mobility, accessibility, and infrastructure studies and their goals for optimization [50]. The neighbourhood allows considering private and public spaces while the "home" and "city" mainly consider the former and latter, respectively [51]. Thus, it enables a classification of the urban system at an intermediate level for holistic understanding and local interventions at which problems originate.

The concept of Environmental Quality is a derivative of natural and human factors interacting at distinct spatial scales. Regional-scale includes a city and its precincts, whereas urban scale is local and includes built forms at the micro and macro level [52-54]. Thus, environmental quality is multidimensional, multi-faceted and multi-disciplinary in nature. Any assessment of the environment requires the integration and exploration of a variety of elements, thus one indicator alone cannot measure environmental quality.

Over time, several types of research have been conducted on the relationship between urban residents and their environment. Bonaiuto et al. [55] studied the relationship between inhabitants and their neighbourhoods of residence in Rome from the environmental psychological view and proposed two distinctive instruments. These instruments consisted of several scales for measuring the perceived environmental qualities of the urban neighbourhoods. While one scale measured factors contributing to neighbourhood attachment, the other scale tried to understand the social environment and its effect on residential satisfaction. Tognoli [56] stated social ties bind people to a neighbourhood; provide social interaction, activity and support. Social relationships can even compensate for poor physical conditions especially in disadvantaged areas.

Pacione [53] from his social geographical perspective, defined quality of life-based on a five-dimensional model to ensure human wellbeing along with UEQ. Robin et al. [57] conducted a study among Parisians. In the end, seven principal dimensions, encountered by the city-dwellers like feelings of insecurity, problems associated with use of public transport, environmental annoyances associated with sharing of public spaces amongst different users, lack of efficiency resulting from the density of the population, etc. emerged and showed a significant relationship of their dissatisfaction of living in such an environment.

Research on the physical environment has certainly confirmed the relationship between social class and the environmental quality of living environments [53]. In general, higher socio-economic groups are more likely to experience residential satisfaction that is directly related to the sharp increase in residential quality with increasing social position [58], and the mobility and choice available in residential environments. Fobil et al. [59] evaluate the relationship between socio-economic conditions and NEQ in Accra, Ghana. The results show wide variation in levels of association between the socio-economic variables and environmental conditions, with strong evidence of a real difference in environmental quality across the different socioeconomic classes. Similarly, Shieh et al. [60] study residential satisfaction in two neighbourhoods of Tehran based on (1) satisfaction with the neighbourhood in terms of litter, malodor, lack of facilities, safety, pollution, crowding and noise; (2) satisfaction with dwelling w.r.t size, upkeep, facilities and costs; and (3) types of neighbours. The study shows dwelling size as the most significant attribute of residential satisfaction and points out that in addition to psycho-social, economic and physical attributes, attributes of the built environment are 
relevant attributes of environmental quality. Another study by Discoli et al. [61] explores the theoretical and conceptual aspects of urban life quality (ULQ) in La Plata, Argentina. A model considering the interactions between basic services, infrastructure and environmental aspects is synthesized to identify inhabitants' satisfaction or dissatisfaction with the above aspects. The study by Delsante et al. [62] considers medium-density neighbourhoods in Lodi and Genoa, Italy with population densities ranging from $25-75 \mathrm{pph}$ for evaluation of UEQ. The assessment is based on a specific set of 74 indicators [63], described through quantitative and qualitative variables. The study establishes that different sets of indicators can be created according to specific research aims, such as targeting different densities like high-density neighbourhoods or urban sprawl. The study further states that even though there are some meaningful sets of indicators corresponding to neighbourhoods, there remains substantial opportunity for further research and experimentation [64], especially in relation to various densities [65]. Lately, Chaguetmi and Derradji's [66] study suggests the application of a holistic method that includes both subjective and objective aspects is necessary to determine the advantages and the dysfunctions of neighbourhoods.

In the Asian context, Kimhi's [67] work on UEQ emphasizes on the quality of the intra-urban environment by considering physical parameters for the state of Israel. The principal recommendations are in the following domains: transportation, noise, air quality, the relationship between population density and open spaces and the quality of life in residential neighbourhoods. Majumdar et al. [68] study the residents' perception of the different environmental aspects of Chittagong Metropolitan City, Bangladesh and conclude that degree of satisfaction varies with income groups and is dependent on quality of infrastructure and their appropriate management. The research is also able to create UEQ maps of 41 wards of the city to show the spatial pattern of UEQ for Chittagong Metropolitan City. Rahman et al. [69] study the urban environment quality of East district of Delhi, India using GIS and remote sensing techniques, which is experiencing very high urban growth with $98.75 \%$ urban population in 2001.

Eight parameters which affect the UEQ are selected, namely built-up area, open spaces, household density, occupancy ratio, population density, accessibility to roads, noise and smell affected area. The study shows that the quality of environment has degraded over the years. Similarly, the study by Patel [36] is an attempt to set a framework on understanding densities and its relation to other factors that contribute to desirable urban living. The paper studies the interrelationships of six parameters: public ground per capita, built up area per capita, plot factor, floor space index, gross densities and net densities. It aims to arrive for a range of desirable values for a combination of these parameters while designing and planning an area between 20 and 200 hectares of land. The data is analyzed by plotting characteristics of select localities in Mumbai and New York. While this paper misses many other sustainability aspects, it is one of the first attempts to answer the question of optimal densities in Indian cities.

Thus, the literature review helps in understanding the various indicators that need to be considered for the assessment of environmental quality - physical, social, economic, geographical, psychological, etc. Additionally, one is able to comprehend several types of quality indexes generated for classifying residential neighbourhoods based on livability/quality of life, quality of environment and/or people's perception of their residential environment as indicated in Table 2. It also helps in gaining knowledge about methods generally adopted for evaluating UEQ at the neighbourhood level. The review also throws light on the fact that studies taking into account physical aspects of the built environment and their impact on environmental quality as compared to social, economic, geographical and psychological factors are sparsely reported and quite scanty in number thus justifying the scope of the present work.

Table 2. Literature review summary - indicators and indexes of environmental quality

\begin{tabular}{|c|c|c|c|}
\hline S.No. & Researcher & Premise of Study & Parameters/Indicators or Index \\
\hline 1. & $\begin{array}{l}\text { Tognoli, } 1987 \\
\text { (US) }\end{array}$ & $\begin{array}{l}\text { Social Environment and Residential } \\
\text { Satisfaction }\end{array}$ & $\begin{array}{l}\text { - Social Interaction } \\
\text { - Activity Intensity } \\
\text { - Support } \\
\text { - Physical Condition of Neighbourhood } \\
\end{array}$ \\
\hline 2. & $\begin{array}{l}\text { Bonaiuto et al., } \\
1999 \text { (Italy) }\end{array}$ & $\begin{array}{l}\text { Relationship between inhabitants and their } \\
\text { neighbourhood from environmental } \\
\text { psychological perspective }\end{array}$ & $\begin{array}{l}11 \text { indexes measure perceived environmental quality }+1 \text { index } \\
\text { measures neighbourhood attachment }\end{array}$ \\
\hline 3. & $\begin{array}{l}\text { Pacione, } \quad 2003 \\
\text { (Scotland) }\end{array}$ & $\begin{array}{l}\text { UEQ and human well-being from social } \\
\text { geographical perspective }\end{array}$ & $\begin{array}{l}\text { Five dimensional model to study quality of life: Subjective \& } \\
\text { Objective Indicators and Social Groups at National, Regional } \\
\text { and Local Levels }\end{array}$ \\
\hline 4. & $\begin{array}{l}\text { Robin et al., } 2007 \\
\text { (France) }\end{array}$ & $\begin{array}{l}\text { Social and Physical Environment and } \\
\text { Residents' Perception }\end{array}$ & $\begin{array}{l}\text { - Feeling of insecurity } \\
\text { - Inconveniences with using public transport } \\
\text { - Environmental annoyances } \\
\text { - Time related to using cars } \\
\text { - Sharing of public spaces } \\
\text { - Lack of efficiency as a result of density of population } \\
\text { - Run-down living environment. } \\
\end{array}$ \\
\hline 5. & $\begin{array}{l}\text { Fried, } 1982 \text { (US) } \\
\text { and Pacione, } 2003\end{array}$ & & $\begin{array}{l}\text { Residential Quality, Choice of Residence and Type of Mode of } \\
\text { Transport }\end{array}$ \\
\hline 6. & $\begin{array}{l}\text { Fobil et al., } 2010 \\
\text { (Ghana) }\end{array}$ & Socio-economic Factors and UEQ & $\begin{array}{l}\text { - Total waste generation } \\
\text { - Waste collection rate } \\
\text { - Sewer disposal rate } \\
\text { - Non-sewer disposal and } \\
\text { - Proportion of households using public toilets } \\
\end{array}$ \\
\hline
\end{tabular}




\begin{tabular}{c|l|l|l}
\hline S.No. & \multicolumn{1}{|c|}{ Researcher } & \multicolumn{1}{|c}{ Premise of Study } & \multicolumn{1}{c}{ Parameters/Indicators or Index } \\
\hline 7. & $\begin{array}{l}\text { Shieh et al., 2011 } \\
\text { (Iran) }\end{array}$ & $\begin{array}{l}\text { Psycho-social, Economic, Physical and } \\
\text { Built Environment Attributes and } \\
\text { Residential Satisfaction }\end{array}$ & $\begin{array}{l}\text { - Satisfaction with the Neighbourhood } \\
\text { Satisfaction with the Dwelling } \\
\text { - Satisfaction with the Neighbours }\end{array}$ \\
\hline 8. & $\begin{array}{l}\text { Patel, 2011 } \\
\text { (US and India) }\end{array}$ & Densities for Good Living Condition & $\begin{array}{l}\text { Interrelationships b/w six urban design parameters - } \\
\text { BUA/Capita, PGA/Capita, FSI, Plot Factor, Net Density and } \\
\text { Gross Density }\end{array}$ \\
\hline 9. & $\begin{array}{l}\text { Discoli et al., 2014 } \\
\text { (Argentina) }\end{array}$ & $\begin{array}{l}\text { Qualitative and quantitative evaluation of } \\
\text { the basic needs of the inhabitants for present } \\
\text { and future planning }\end{array}$ & $\begin{array}{l}\text { Basic services, infrastructure and environmental aspects are } \\
\text { synthesized into a model to identify residents' satisfaction or } \\
\text { dissatisfaction }\end{array}$ \\
\hline 10. & $\begin{array}{l}\text { Delsante et al., } \\
\mathbf{2 0 1 4} \\
\text { (Italy) }\end{array}$ & $\begin{array}{l}\text { Assessing environmental quality for } \\
\text { different densities }\end{array}$ & $\begin{array}{l}\text { Set of 74 indicators divided into 4 domains - Architecture \& } \\
\text { Urban Design, Use \& Accessibility, Landscape \& Environment } \\
\text { and Social \& Community }\end{array}$ \\
\hline
\end{tabular}

Table 3. Literature review summary - type and nature of impacts of increasing density

\begin{tabular}{|c|c|c|}
\hline \multirow[t]{2}{*}{ Type of impact } & \multicolumn{2}{|c|}{ Nature of impacts } \\
\hline & Positive impacts & Negative impacts \\
\hline \multirow{4}{*}{$\begin{array}{l}\text { Environmental } \\
\text { impacts }\end{array}$} & \multicolumn{2}{|c|}{ Direct Impacts } \\
\hline & $\begin{array}{l}\text { - Land occupation is reduced } \\
\text { - Reduction of urban sprawl } \\
\text { - Reduction in travel distances } \\
\text { - Increased feasibility of public transport } \\
\text { - Reduced length of utility networks } \\
\text { - Reduced solar gain due to mutual shading of buildings }\end{array}$ & $\begin{array}{l}\text { - Exploitation of urban greens and open spaces } \\
\text { - Danger of exhaustion of water source } \\
\text { - Water Pollution } \\
\text { - Increase in Traffic Volume } \\
\text { - Increased Waste Generation } \\
\text { - Dense urban form reduces access to natural/day light and } \\
\text { ventilation } \\
\text { - Reduced aesthetics due to overcrowding }\end{array}$ \\
\hline & \multicolumn{2}{|c|}{ Indirect Impacts } \\
\hline & $\begin{array}{l}\text { - Reduced carbon footprint } \\
\text { - Reduced car dependence } \\
\text { - Reduced demand for fuel } \\
\text { - Less energy usage for infrastructure provision such as } \\
\text { roads and pipelines }\end{array}$ & $\begin{array}{l}\text { - Reduced level of service and increased travel time } \\
\text { - Increase in Vehicular Pollution (Air and Noise) } \\
\text { - Land and water pollution as a result of increased waste } \\
\text { generation and insufficient infrastructure } \\
\text { - Use of more energy intensive building materials for high } \\
\text { rise construction } \\
\text { - Higher GHG Emissions due to more lighting, ventilation } \\
\text { and cooling requirements of high rise buildings }\end{array}$ \\
\hline Social impacts & $\begin{array}{l}\text { - Social Service Provision such as schools, hospitals etc. } \\
\text { becomes feasible } \\
\text { - Greater social interaction } \\
\text { - Public surveillance of streets } \\
\text { - Increased walkability }\end{array}$ & $\begin{array}{l}\text { - Congestion and overcrowding } \\
\text { - Rise in crime } \\
\text { - Reduced hygiene leading to ill health } \\
\text { - Loss of privacy }\end{array}$ \\
\hline $\begin{array}{l}\text { Economic } \\
\text { impacts }\end{array}$ & $\begin{array}{l}\text { - Reduction in transportation costs } \\
\text { - Reduction in construction costs in case of shared walls } \\
\text { - Lower rents observed in dense residential areas } \\
\text { - Service provision cheaper } \\
\text { - Reduction in cost of living }\end{array}$ & $\begin{array}{l}\text { - High rise development is cost intensive } \\
\text { - Increased land prices } \\
\text { - Overcrowding and reduced aesthetics may bring down } \\
\text { real estate value }\end{array}$ \\
\hline
\end{tabular}

It is observed that impacts can be broadly segregated into three types namely environmental, social and economic impacts. Further, there are positive and negative impacts in each of the categories. A deeper understanding also enables one to comprehend that certain impacts are direct and others are indirect that is they accrue as a result of the direct impacts. This is significantly observed in the case of the environmental impacts as in Table 3.

Even though all the listed impacts are significant, those responsible for the poor environmental quality in residential neighbourhoods are acknowledged as one of the most urgent and greatest problems for our cities because of the immediate risk they present to the inhabitants' health. Accordingly, crowding and congestion; decay of parks and open spaces; air and water pollution; increasing waste generation; decreasing levels of cleanliness and failure of sewerage and drainage systems (services); decreasing sense of safety; increasing noise pollution; rising temperatures caused due to urban heat island (UHI) effect; reduced natural ventilation and daylight are amongst the most significant impacts. This view can be further corroborated by several studies that directly show how these aspects of the environment affect child and family wellbeing [70, 71].

While crowded living conditions have adverse impact on several child outcomes, housing quality affects their socioemotional development. Similarly, there is evidence of the importance of parks and green spaces for child development contact with nature may be as important to children as good nutrition and adequate sleep. Polluted air and water affect both cognitive and socio-emotional development while chronic exposure to noise in the forms of transportation, music, and other people has adverse effects on people's cognitive development (reading levels, long-term memory), psychophysiology (blood pressure, hormone levels and associated stress), mental health and motivation [72-76]. 


\section{AN ADAPTIVE INDICATOR FRAMEWORK FOR ASSESSING (NEQ)}

All the impacts like crowding and congestion; air and water pollution; waste generation; levels of cleanliness and sewerage and drainage systems (services); noise pollution; temperature variation at various levels of the locality; natural light, ventilation; etc. if carefully observed are measurable parameters. In fact, they can be considered as indicators that can be measured and aggregated to give objective values of NEQ. Thus, based on literature review, it is important to understand and identify the variables to measure these indicators so that they can be used for further study and analyses.

The first attribute considered to have influence on the urban environment is Population Density. High density of people in a given locality results in increased congestion, which puts pressure on infrastructure. This impacts the environment quality of the locality, resulting in high levels of discomfort. Physical congestion is a variable derived from various measures like count of households per unit area, average number of vehicles traversing on roads, activities and their concentration, etc. Hence, population density along with residential density, built-form characteristics like plot size, plot coverage and amount of open spaces help in determining built-up area per capita (BUA/Capita), public ground area per capita (PGA/Capita), paved road length per capita (PRL/Capita) and mobilization factor (M.F) [77]. These parameters help in indicating the neighborhood environment quality by operationalizing and ascertaining the level of congestion or crowding (internal and external).

Open spaces can be either in the form of parks and playgrounds, or some vacant spaces, or waste land or agricultural land and water bodies. Parks and playground within the residential neighborhoods act as lungs for the urban residents without which it is very difficult to live in a city with an environment affected by dust, pollution and other atmospheric hazards [78]. The trees and plants growing in parks reduce the pollution amounts in the air, affect the microclimate (cause temperature variations) by evaporative cooling and also serve as recreational sources for the locality. Similarly, the play-grounds besides providing sports opportunity for the residents also relieve congestion [79-81].

Apart from classification and defining the types of open space, the intention is to define the spatial qualities and utilization levels of these spaces. Specific variables include: the type of open space and its effect on the activity diversity and activity intensity of the space. While activity diversity refers to the number of different types of activities taking place in an open space, activity intensity refers to the number of users per square area (meters, hectares, etc.). Activity intensity as applied in this study implies the degree of utilization of space [82]. More the diversity and better the utilization, higher is its contribution to the quality of the place. Further, condition of the open spaces in terms of maintained or unattended, encroached and percentage tree cover evaluate the environmental quality of the space [83].

Ventilation and presence of shade from plants is of vital importance to improve the micro-climate and enhance comfort living in cities with composite or semi-arid type of climate one of the main climatic zones found in the Indian subcontinent. The outdoor environmental quality is primarily dictated by the degree of exposure to cross ventilation and shade from trees to buildings and outdoor spaces. Too compactly laid down houses have poor qualities in terms of facilitating cross ventilation. With regard to significance of shade trees, Kyhn [84] notes that: Shade trees filter the sunlight, reduce air temperature by evaporation, protect smaller plants on the ground and reduce glare from bright overcast skies. Thus, variables like street orientation, building height to street width ratio and percentage tree cover can aid in assessing ventilation, shade and temperature variations, if any [85].

As the densities increase in urban areas, the prevalent technology becomes incapable of catering to concentrated demands. Thus, slowly the existing facilities and services fail to cater to the population pressure. The environmental quality can be evaluated with reference to provision of services like condition of roads, sidewalks, installation of street lights, types of open spaces, drainage and sewerage along with disposal of domestic waste. The assumptions here are that each of the localities or census wards are closed units of study - the services considered are largely of local neighbourhood use and relevance; and inter-ward use of services is negligible. Big schools, hospitals, etc. are not considered because they are higher order services that are not tenable at the neighbourhood level. The quality of walking requirement could be ascertained based on proximity to daily needs, condition of sidewalks and adequacy of streetlights, etc. To ensure walkable neighbourhoods and assess overall environment as part of present study these indicators become very significant.

Table 4. Indicator framework to assess NEQ

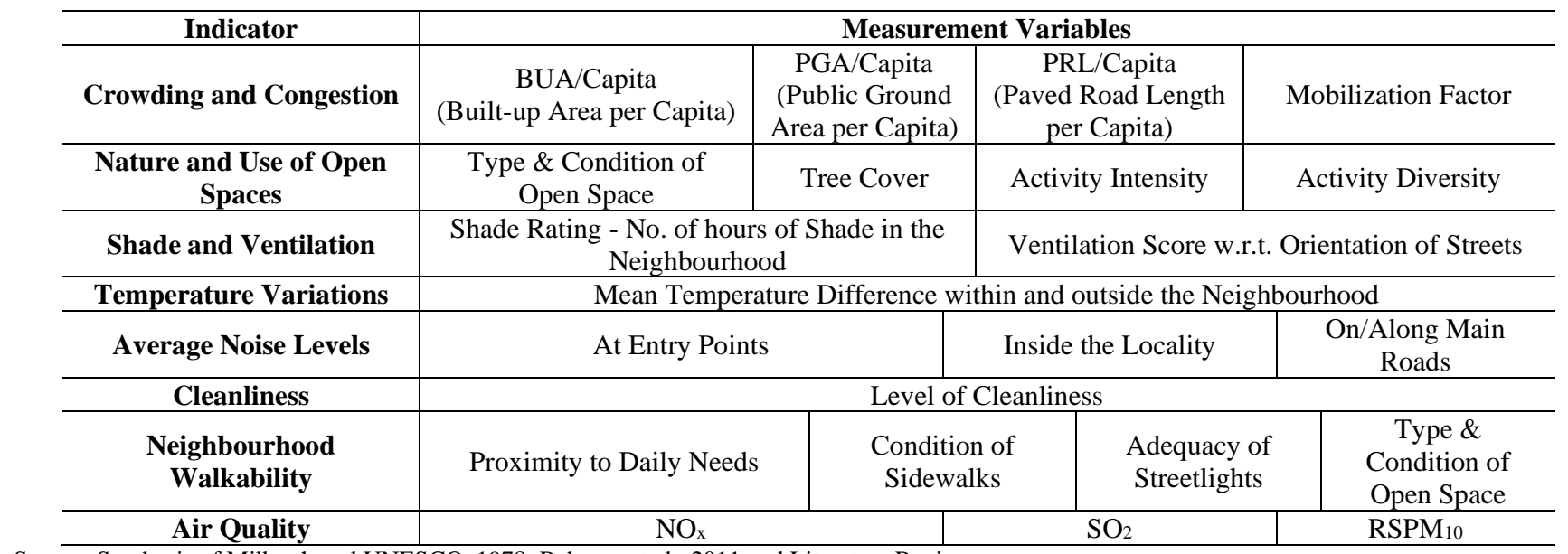

Source: Synthesis of Milbrath and UNESCO, 1978; Rahman et al., 2011 and Literature Review 
Air quality is the only indicator that is measured using $\mathrm{NO}_{\mathrm{x}}$, $\mathrm{SO}_{2}$ and $\mathrm{RSPM}_{10}$ values dependent on other variables like type and area of open space, percentage tree cover, vehicles on road, etc. and compared with national standards. These three pollutants among others are primarily considered as they are most noticeable sources of air pollution in residential areas [86]. Similarly, noise levels are also compared with national standards as laid down for residential areas.

The indicators in Table $4[69,87]$ examine the environmental quality in relation to the density variables. The spatial quality as applied to this study refers to the basic prerequisites for effective use of spaces within identified and selected residential patterns. The argument here is that irrespective of the context, there are basic planning and design requirements that facilitate environmentally conducive growth and utilization of spaces. If such requirements are missing, then utilization of spaces becomes poor and environmental quality unfavorable.

\section{CONCLUSION}

The literature review brings forth the key issue concerning environmentally sustainable development of cities in the wake of rapid urbanization and identifies cities that signify the future urbanization pattern of India. Studies reveal that smaller cities are going to accommodate larger number of people in near future and become centers of economic growth and development.

Based on observations, it can be concluded that certain specific patterns are visible and it is quintessential to understand the residential patterns of different cities and their associated local environmental problems to establish a relationship between various variable of residential pattern like population distribution, distribution of built forms, built form characteristics and environmental quality.

The paper also tries to understand the term physical density and the common measures adopted to define the various types of physical density like people density, building density and spatial density. Population density in the context of Indian cities is studied thoroughly and it is found that most cities have low average densities, but core areas have greater demand for public transit systems and interventions for improving overall quality of urban spaces owing to their significant high densities. It is also seen that several efforts have been made by the town and country planning department and other government bodies of different states of the country to increase the density of population in case of plotted and group housing developments in an attempt to meet the challenges of providing quality housing in India's urban areas.

FAR - an important measure of building density along with other building regulations like height, plot coverage, etc. are compared across different cities, both national and international. It is seen that most of the cities have their own set of rules and regulations as considered appropriate with respect to the population distribution, mix of housing, type of infrastructure and future development strategies. It is also understood that higher FAR or FSI does not necessarily imply high density. Density depends on the floor space occupied by each resident and several other factors need to be considered as to the maximum height that can be built taking into account different residential patterns, infrastructural needs and mindset of the people.

Next, the term spatial density is defined. Several studies indicate that the social environment is directly linked to the layout and built form or the spatial and physical characteristics of the urban neighbourhood. Information from different websites is gathered and several government documents and reports like URDPFI 2014, Handbook of Service Level Benchmarking of MoUD, Govt. of India, etc. are studied to find out the norms vis-à-vis the actual condition of the various parameters like distribution of open spaces, distribution of roads, streetlights, sewerage and drainage services etc. that measure spatial density. It is observed that the standard of most of the parameters is below the suggested norms resulting in poor environmental quality in our rapidly urbanizing cities.

Following this, the term environmental quality is defined and the justification of studying it at the neighbourhood level is established. Subsequently, the various indicators and methods considered for the assessment of environmental quality are identified from the works of several researchers. The literature review reveals that studies taking into account physical aspects of the built environment and their impact on NEQ are quite few especially in the Indian context or are sparsely reported, thus justifying the scope of the present work.

The paper concludes with the discussion of impacts of increasing density on environmental quality. Several impacts are identified based on the background studies and all of them are broadly categorized into three types - environmental, social and economic impacts. Further they are classified as positive and negative, and direct and indirect impacts. Considering the significance of impacts, those responsible for poor environmental quality in residential neighbourhoods are acknowledged as the most urgent and greatest because of the immediate risk they present to the inhabitants' health and wellbeing. Accordingly, crowding and congestion; decay of parks and open spaces; air and water pollution; increasing waste generation; decreasing levels of cleanliness and failure of sewerage and drainage systems (services); decreasing sense of safety; increasing noise pollution; temperature variations within the locality; reduced access to both natural ventilation and daylight are identified as the most significant impacts.

Finally, the paper ends with the identification of a set of indicators and variables that have all been sourced from the literature review to measure NEQ. These form the basis of the indicator framework for further research and analyses.

\section{ACKNOWLEDGMENT}

Useful comments were received from the reviewers. The findings, interpretations and conclusions expressed here are only those of the authors, and do not represent the views of their organizations or any other organizations that have provided institutional or organizational support for the preparation of this paper.

\section{REFERENCES}

[1] Dutta, S., Bardhan, S., Bhaduri, S. (2013). Patterns of urbanization and environmental quality in the context of Indian cities. Environment and Urbanization ASIA, 4(2): 287-299. https://doi.org/10.1177/0975425313510768

[2] Piracha, A.L., Marcotullio, P.J. (2003). Urban ecosystem analysis - identifying tools and methods. UNU/IAS Report. https://doi.org/10.13140/RG.2.1.5055.4963

[3] Kochhar, R. (2015). A global middle class is more 
promise than reality. From 2001 to 2011, Nearly 700 Million Step Out of Poverty, but Most Only Barely. Washington, D.C., Pew Research Center.

[4] Sandhu, K., Gill, G.S. (2010). Impact of urban paraphernalia on amritsar city: Of transformations and transgressions. Sri Lankan Journal of Real Estate, 4: 117.

[5] Chaudhry, P., Singh, B., Tewari, V.P. (2007). Nonmarket economic evaluation in developing countries: Role of participant observation method in CVM analysis. Journal of Forest Economics, 13(4): 259-275. http://dx.doi.org/10.1016/j.jfe.2006.12.001

[6] Singh, V.S., Pandey, D.N., Chaudhry, P. (2010). Urban Forests and open green spaces: Lessons for Jaipur, Rajasthan, India. Urban Forests and Open Green Spaces, $1-22$.

[7] Chaturvedi, A., Kamble, R., Patil, N.G., Chaturvedi, A. (2013). City-forest relationship in Nagpur: One of the greenest cities of India. Urban Forestry \& Urban Greenery, $12(1)$ : 79-87. https://doi.org/10.1016/j.ufug.2012.09.003

[8] Chaudhry, P., Sharma, M.P., Singh, G., Bansal, A. (2013). Valuation of urban environmental amenities in developing countries-A case study from Chandigarh, India. Global Journal of Science Frontier Research, 13(2): $1-13$.

[9] Vailshery, L.S., Jaganmohan, M., Nagendra, H. (2013). Effect of street trees on microclimate and air pollution in a tropical city. Urban Forestry \& Urban Greening, 12(3): 408-415. https://doi.org/10.1016/j.ufug.2013.03.002

[10] Carmona, M. (2019). Place value: place quality and its impact on health, social, economic and environmental outcomes. Journal of Urban Design, 24(1): 1-48. https://doi.org/10.1080/13574809.2018.1472523

[11] Jon, I. (2020). A manifesto for planning after the coronavirus: Towards planning of care. Planning Theory, 19(3): 329-345 https://doi.org/10.1177/1473095220931272

[12] World Wide Fund for Nature (WWF). (2010). Urbanisation and Sustainability in India: An Interdependent Agenda. The Alternative Urban Futures Report 2010 http://assets.wwfindia.org/downloads/urbanisation_repo rt.pdf.

[13] Indian Institute for Human Settlements (IIHS). (2011). Urban India 2011: Evidence. India Urban Conference: Evidence and Experience (IUC 2011), IIHS, India. http://iihs.co.in/knowledge-gateway/wpcontent/uploads/2015/08/IUC-Book_02-03-12-LOWRES.pdf.

[14] United Nations, Department of Economic and Social Affairs, Population Division. (2019). World Urbanization Prospects: The 2018 Revision (ST/ESA/SER.A/420). New York: United Nations. https://population.un.org/wup/Publications/Files/WUP2 018-Report.pdf.

[15] Galster, G., Hanson, R., Wolman, H., Coleman, S., Freihage, J. (2001). Wrestling sprawl to the ground: defining and measuring an elusive concept. Housing Policy Debate, 12(4): 681-717. https://doi.org/10.1080/10511482.2001.9521426

[16] Kapadia, K. (2010). The sustainable Indian cities - an oxymoron. Context: Journal of the Development and Research Organisation for Nature, Arts and Heritage,
7(2): 41-47.

[17] Smailes, A.E. (1986). The Indian City: A Descriptive Model. In: V.K. Tewari, J.A. Weinstein and V.L.S. Prakasa Rao (Eds.), Indian Cities Ecological Perspectives, New Delhi: Concept Publishing Company, pp. 35-54.

[18] Chaubey, R., Kapoor, S. (2015). Impediments to growth and development of a cantonment town - A study of Mhow town of Madhya Pradesh. PhD. Dissertation, Devi Ahilya Vishwavidyalaya, Indore.

[19] Bharne, V. (2011). Enabling responsible urban form. The Urban Vision - Posted in Opinion and Blogs on 9 April 2011.

[20] Raje, A.P. (2015). Who owns the city? Livemint E Paper, 14 January 2015.

[21] Breheny, M. (1992). Sustainable Development and Urban Form. London: Pion Limited.

[22] Jelinek, G. (1992). Aspects of density in urban and residential planning for jabotabek. Trialog, 32: 8-14.

[23] Alexander, E. (1993). Density measures: A review and analysis. Journal of Architectural and Planning Research, 10(3): 181-202.

[24] Acioly, C., Davidson, F. (1996). Density in urban development. Building Issues, 8(3): 3-25.

[25] Rådberg, J. (1996). Towards a Theory of Sustainability and Urban Quality: A New Method for Typological Urban Classification. In: M. Gray (Ed.) Evolving Environmental Ideals: Changing Ways of Life, Values and Design Practice, Book of Proceedings for the 14th Conference of the International Association for PeopleEnvironment Studies, Stockholm, Sweden: Royal Institute of Technology 1996, 384-392.

[26] Churchman, A. (1999). Disentangling the concept of density. Journal of Planning Literature, 13: 389-411. https://doi.org/10.1177/08854129922092478

[27] Gómez Arenas, A. (2002). Analysis of infrastructure provision in low-income settlements, Port Elizabeth South Africa. Master's Thesis, EESI Programme, Royal Institute of Technology, Stockholm.

[28] Cheng, V. (2010). Understanding density and high density. In: Edward Ng. (Ed.), Designing High Density Cities - For Social and Environmental Sustainability, New York: Earthscan, pp. 3-17. https://doi.org/10.4324/9781849774444-11

[29] Demographia. (2014). Demographia World Urban Areas (Built-up Urban Areas or World Agglomerations), 10th Annual Edition: March 2014. http://cdn.plataformaurbana.cl/wpcontent/uploads/2014/ 04/1398448369_demographia_world_urban_areas_repo rt.pdf.

[30] Pandit, S. (2016). Urban density. https://cidcosmartcity.niua.org/urban-density/.

[31] Ray, S. (2012). Sustainable Urban Form for Indian Cities http://www.cityform.org/india/pdf/Cityform\%20Confer ence\%209th\%20Jan-\%20Satmohini.pdf.

[32] Dash, D.K. (2011). Population density of group housing societies raised to 300 persons per acre. The Economic Times, Times of India 30 May 2011. http://timesofindia.indiatimes.com/city/Gurugram/.

[33] Town and Country Planning Organisation (TCPO) (2014). Urban and Regional Development Plans Formulation and Implementation (URDPFI) Guidelines. Ministry of Urban Development, Government of India. http://moud.gov.in/upload/uploadfiles/files/URDPFI\%2 
0Guidelines\%20Vol\%20I.pdf.

[34] Dutta, S., Bardhan, S., Bhaduri, S. (2017). Density and neighbourhood environmental quality - a comparative study in the context of Indian cities. SPECIAL ISSUE of International Journal on Emerging Technologies (IJET), 8(1): 315-323.

[35] Mishra, S. (2016). At a Glance: FSI in 10 Cities of India. https://www.proptiger.com/guide/post/fsi-in-10-citiesof-india.

[36] Patel, S.B. (2011). Analyzing urban layouts - can high density be achieved with good living conditions? Environment and Urbanisation, 23(2): 583-595. https://doi.org/10.1177\%2F0956247811418737

[37] Patel, S.B. (2014). Housing, FSI, Crowding and Densities. Handbook Vol. I. Mumbai: Praja Foundation.

[38] Ramnani, V. (2016). Purchasable FAR will create more problems for Gurugram. The Hindustan Times, 6 Aug 2016. http://www.hindustantimes.com/real-estate/.

[39] Dave, S. (2010). High Urban densities in developing countries: A sustainable solution? Built Environment, 36(1): 9-27. https://doi.org/10.2148/benv.36.1.9

[40] Raman, S. (2010). Designing a livable compact city: Physical forms of city and social life in urban neighbourhoods. Built Environment, 36(1): 63-80.

[41] Correa, C. (1982). Architecture in a warm climate. MIMAR Architecture in Development, 5: 31-35.

[42] Curtis, W.J.R. (1988). Balkrishna Doshi: An Architecture for India. New York: Rizzoli.

[43] Rajadhyaksha, M. (2012). You have just 1.1 square meters of open space. The Economic Times, Times of India, 28 May 2012.

[44] Eeshanpriya, M.S. (2018). Mumbai to get more open space per person. Hindustan Times E Paper, 27 April 2018. https://www.hindustantimes.com/mumbainews/mumbai-to-get-more-open-space-perperson/story-5BtDAXun2YvuEJm3pvw6NM.html.

[45] Udas-Mankikar, S. (2020). Formulating open-space policies for India's Cities: The case of mumbai. ORF Occasional Paper No. 241, Observer Research Foundation. $\quad$ https://www.orfonline.org/wpcontent/uploads/2020/04/ORF_OccasionalPaper_241_O pen_Spaces.pdf.

[46] Ministry of Road Transport and Highways (MoRTH). (2017). Basic Road Statistics of India (2016-17). New Delhi: Transport Research Wing, MoRTH, GoI https://morth.nic.in/sites/default/files/Basic\%20_Road_ Statics_of_India.pdf.

[47] Debu, C. (2015). Street lighting in India and need for energy-efficient solutions. MapsofIndia.com - Posted on 26 Feb 2015. http://www.mapsofindia.com/myindia/government/street-lighting-in-india-and-need-forenergy-efficient-solutions.

[48] Livemint E Paper. (2016). The alarming deficit in stormwater drainage in urban India. http://www.livemint.com/Politics/pL6qalnBUQmulQZ RuorELP/The-alarming-deficit-in-stormwater-drainagein-urban-India.html.

[49] Times of India. (2013). Around 80\% of sewage in Indian cities flows into water systems http://timesofindia.indiatimes.com/home/environment/p ollution/Around-80-of-sewage-in-Indian-cities-flowsinto-water-systems/articleshow/18804660.cms.

[50] Delsante, I. (2016). Urban environment quality assessment using a methodology and set of indicators for medium-density neighbourhoods: A comparative case study of Lodi and Genoa. Ambiente Construído, Porto Alegre, 16(3): 7-22. http://dx.doi.org/10.1590/s167886212016000300089

[51] Bonaiuto, M., Fornara, F., Bonnes, M. (2003). Indexes of perceived residential environmental quality and neighbourhood attachment in urban environments: A confirmation study on the city of Rome. Landscape and Urban Planning, 65(1-2): 41-52. https://doi.org/10.1016/S0169-2046(02)00236-0

[52] van Kamp, I., Leidelmijer, K., Marsman, G. and de Hollander, A. (2003). Urban environmental quality and human well-being - Towards a conceptual framework and demarcation of concepts; a literature study. Landscape and Urban Planning, 65(1-2): 5-18. https://doi.org/10.1016/S0169-2046(02)00232-3

[53] Pacione, M. (2003). Urban environmental quality and human wellbeing - a social geographical perspective. Landscape and Urban Planning, 65(1-2): 19-30. https://doi.org/10.1016/S0169-2046(02)00234-7

[54] Nichol, J., Wong, M.S. (2005). Modeling urban environment quality in a tropical city. Landscape and Urban Planning, 73: 49-58. https://doi.org/10.1016/j.landurbplan.2004.08.004

[55] Bonaiuto, M., Aiello, A., Perugini, M., Bonnes, M., Ercolani, A.P. (1999). Multidimensional perception of residential environment quality and neighbourhood attachment in the urban environment. Journal of Environmental Psychology, 19(4): 331-352. https://doi.org/10.1006/jevp.1999.0138

[56] Tognoli, J. (1987). Residential Environments. In: Stokols, D., Altman, I. (Eds.). Handbook of Environmental Psychology, Vol. 1 (pp. 655-690). New York: John Wiley \& Sons, Inc.

[57] Robin, M., Matheau-Police, A., Couty, C. (2007). Development of a scale of perceived environmental annoyances in urban settings. Journal of Environmental Psychology, 27(1): 55-68. https://doi.org/10.1016/j.jenvp.2006.09.005

[58] Fried, M. (1982). Residential Satisfaction: Sources of residential and community satisfaction. Journal of Social Issues, 38(3): 107-119.

[59] Fobil, J., May, J., Kraemer, A. (2010). Assessing the relationship between socioeconomic conditions and urban environmental quality in accra, Ghana. International Journal of Environmental Research and Public Health, 7(1): 125-145. https://doi.org/10.3390/ijerph7010125

[60] Shieh, E., Sharifi, A., Rafieian, M. (2011). Identification of factors that assure quality of residential environments, using environmental assessment indices: a comparative study of Two of Tehran's neighbourhoods (Zafaranieh \& Khaniabad). International Journal of Architectural Engineering and Urban Planning, 21(2): 119-132.

[61] Discoli, C., Martini, I., San Juan, G., Barbero, D., Dicroce, L., Ferreyro, C., Esparza, J. (2014). Methodology aimed at evaluating urban life quality levels. Sustainable Cities and Society, 10: 140-148. https://doi.org/10.1016/j.scs.2013.08.002

[62] Delsante, I. (2014). Indicators for urban quality evaluation at neighbourhood scale and relationships with health and wellness perception. In: Proceedings of World Sustainable Building Conference, Barcelona.

[63] Delsante, I. (2007). Identità e Promozione Della Salute. 
In: Rinnovo Urbano (Editore), Santarcangelo di. Romagna: Maggioli.

[64] Damen, R.G. (2014). Evaluating Urban Quality and Sustainability: presentation of a framework for the development of indicator assessment methods, by which the existing urban environment may be evaluated on quality and sustainability performance on a neighbourhood scale. Master's Thesis, University of Twente, Enschede, Netherlands.

[65] Lee, G.K.L., Chan, E.H.W. (2009). Indicators for evaluating environmental performance of the Hong Kong urban renewal projects. Facilities, 27(13/14): 515-530.

[66] Chaguetmi, F., Derradji, M. (2020). Assessment of the environmental quality of neighbourhoods in the context of sustainable development: Case of the Plain West in Annaba, Algeria. Environ Dev Sustain, 22: 4563-4588. https://doi.org/10.1007/s10668-019-00398-1

[67] Kimhi, I. (2005). (Ed.) Urban Environmental Quality. The Centre for Environmental Policy, Jerusalem Institute for Israel Studies, Jerusalem.

[68] Majumdar, A.K., Hossain, M.E., Islam, M.N., Sarwar, M.I. (2007). Urban environmental quality mapping: A perception study on chittagong metropolitan city. Kathmandu University Journal of Science, Engineering $\begin{array}{lll}\text { and } & \text { Technology, } & 3(2):\end{array}$ https://doi.org/10.3126/kuset.v3i2.2896

[69] Rahman, A., Kumar, Y., Fazal, S., Bhaskaran, S. (2011). Urbanisation and quality of urban environment using remote sensing and GIS techniques in East Delhi, India. Journal of Geographic Information System, 3: 62-84. https://doi.org/10.436/jgis.2011.31005

[70] Moore, T.G., Fry, R. (2011). Place-based services: A literature review. Centre for Health Equity Training, Research and Evaluation (CHETRE), South Western Sydney Local Health District and UNSW Australia: Liverpool.

[71] UN-HABITAT and World Health Organization (2020). Integrating health in urban and territorial planning: A sourcebook. Geneva. Licence: CC BY-NC-SA 3.0 IGO. https://unhabitat.org/sites/default/files/2020/05/1final_highres_20002_integrating_health_in_urban_and_ territorial_planning_a_sourcebook.pdf.

[72] Evans, G.W. (2006). Child development and the physical environment. Annual Review of Psychology, 57: 423451. https://doi.org/10.1146/annurev.psych.57.102904.19005 7

[73] Huby, M., Bradshaw, J. (2006). A review of the environmental dimension of children and young people's wellbeing (Vol. I). York, UK: University of York.

[74] Louv, R. (2005). Last Child in the Woods: Saving Our Children from Nature-Deficit Disorder. Chapel, North Carolina: Algonquin Books of Chapel Hill.
[75] Louv, R. (2011). The Nature Principle: Human Restoration and the End of Nature-Deficit Disorder. Chapel, North Carolina: Algonquin Books of Chapel Hill.

[76] Wood, L. (2009). Parks and open space: for the health and wellbeing of children and young people. Woden, ACT: Australian Research Alliance for Children and Youth.

[77] Sarmento, R., Zorzal, F.M.B., Serafim, A.J., Allmenroedr, L.B. (2000). Urban Environmental Quality Indicators. In: C.A. Brebbia, A. Ferrante, M. Rodiguez \& B.Terra (Eds.), The Sustainable City. United Kingdom: WIT Press.

[78] Malini, R.S. (1987). Residential densities and living conditions in a metropolis - a case study. PhD. Dissertation, Institute for Social and Economic Change, Bangalore.

[79] Honold, J., Beyer, R., Lakes, T., van der Meer., E. (2012). Multiple environmental burdens and neighborhoodrelated health of city residents. Journal of Environmental Psychology, 32(4): 305-317. https://doi.org/10.1016/j.jenvp.2012.05.002

[80] Timperio, A., Crawford, D., Ball, K., Salmon, J. (2017). Typologies of neighbourhood environments and children's physical activity, sedentary time and television viewing. Health Place, 43(1): 121-127. https://doi.org/10.1016/j.healthplace.2016.10.004

[81] Weber, S., Boley, B.B., Palardy, N., Gaither, C.J. (2017) The impact of urban greenways on residential concerns: findings from the atlanta beltline trail. Landscape and Urban Planning, 167: 147-156. https://doi.org/10.1016/j.landurbplan.2017.06.009

[82] Lupala, J.M. (2001). Peri-urban land management in the rapidly growing cities - the case of dar-es-salaam. $\mathrm{PhD}$. Dissertation, University of Dortmund.

[83] Rosenburg, W.A., Rofè, Y. (2013). Mapping Feeling: An Approach to the Study of Emotional Response to Built Environment and Landscape. Journal of Architectural and Planning Research, 30(2): 127-145.

[84] Kyhn B. (1984). Single Storey Housing in Tanzania. Copenhagen: FSD Publication.

[85] Ko, Y., Radke, J.D. (2014). The effect of urban form and residential cooling energy use in Sacramento, California. Environment and Planning B: Planning and Design, 41(4): 573-593. https://doi.org/10.1068\%2Fb12038p

[86] Central Pollution Control Board (CPCB). (2014). National ambient air quality monitoring status and trends 2014-15. New Delhi: Ministry of Environment and Forests (MoEF). https://www.cpcb.nic.in/.

[87] Milbrath, L.W. (1978). Indicators of environmental quality in UNESCO. Indicators of environmental quality and quality of life - Reports and Papers. Social Sciences, 38: 3-56. 